\title{
Genetic Variability, Heritability and Genetic Advance in Grain Amaranth (Amaranthus spp.)
}

\author{
Sheela N. Malaghan*, S. Revanappa, P.S. Ajjappalavar, \\ M.S. Nagaraja and S. Raghavendra
}

Department of Horticulture, College of Horticulture, Bagalkot, University of Horticultural

Sciences, Bagalkot - 587 103, India

*Corresponding author

\section{A B S T R A C T}

\section{Keywords}

Amaranth, Grain, Genetic variability,

Heritability,

Genetic advance and rabi

\section{Article Info}

Accepted:

10 June 2018

Available Online:

10 July 2018
Forty four germplasm accessions of amaranth spp were evaluated during rabi-2016 for assessing the genetic variability present in the material for grain yield and yield related traits. Analysis of variance revealed significant differences among the genotypes for all the characters studied. High PCV and GCV was observed for number branches per plant, number of panicles per inflorescence, number of inflorescence per plant, panicle length $(\mathrm{cm})$, panicle breadth $(\mathrm{cm})$, thousand seed weight $(\mathrm{mg})$, seed yield per plant $(\mathrm{g})$, inflorescence length $(\mathrm{cm})$, plant height at 90 das $(\mathrm{cm})$ and stem diameter $(\mathrm{cm})$. On the other hand, low PCV and GCV were observed for days to seed maturity. All the traits studied exhibited high heritability. High genetic advance as per cent of mean was observed for number branches per plant, number of inflorescence per plant, number of panicles per inflorescence, panicle length $(\mathrm{cm})$, panicle breadth $(\mathrm{cm})$ and thousand seed weight $(\mathrm{mg})$ and seed yield $(\mathrm{g})$ indicating predominance of additive genetic component in expression of these traits. Thus, there is scope for improvement of seed yield by adopting selection.

\section{Introduction}

Grain Amaranth is a very versatile pseudocereal crop and grown in a wide range of agroclimatic conditions (temperature $20-40^{\circ} \mathrm{C}$, elevation 500-2500 $\mathrm{m}$ from MSL and rainfall $800 \mathrm{~mm}$ to $1500 \mathrm{~mm}$ ). The genus Amaranthus consists of approximately 60 species out of which about 18 species are occurring in India. There are three major grain producing Amaranthus species, A. caudatus, A. cruentus and A. hypochondriacus, all believed to originate from Central and South America
(Sreelathakumary and Peter, 1993; Grubben, 1976). It is one of those rare plants whose leaves are eaten as a vegetable while the seeds are used as cereals. Besides, it is also used as fodder, ornamental, organic red dye and for industrial purposes.

The genus Amaranthus is receiving increasing attention because of the nutritional properties of the grain and leaves and can now be found throughout the world (Schulz- Schaeffer, 1993). It's high in protein, particularly in the amino acid Lysine, which is low in the other 
cereal grains. Amaranth is also rich in many vitamins and minerals. However, Amaranth does not contains gluten and because of this, it's not good for making yeast breads (O'Brien and Price, 1983). The wide geographical spread of the genus has resulted in the evolution of many landraces in widely separated areas forming a huge gene pool. In India, Amaranthus is mainly cultivated in the rural areas and is well adapted to diverse climatic conditions, highly resistance to stresses (including diseases and pests).

The genetic parameters like co-efficient of variation, heritability and genetic advance as per cent of mean provide a clear insight into the extent of variability and a relative measure of the efficiency of selection of genotypes based on phenotype, in a highly variable population. Hence, the present study was carried out to find the genetic parameters for yield and its component traits in grain amaranth.

\section{Materials and Methods}

Field experiment for the present study on grain amaranth was conducted at the research field unit of University of Horticultural Sciences, Bagalkot, Karnataka, during rabi 2015 - 16. The experimental material used in the present study comprised of forty four genotypes of amaranth spp of which thirty five germplasm lines were obtained from National Bureau of Plant Genetic Resources (NBPGR) Regional Station, Shimla, (Himachal Pradesh). Rest of nine used are varieties viz., $\mathrm{CO} 1, \mathrm{CO}$ 2, $\mathrm{CO} 3, \mathrm{CO} 4, \mathrm{CO} 5$, Arka suguna, Arka samraksha, Arka arunima and Arka varna. The experiment was laid out in RBD with two replications. In each replication, each entry was grown in two rows at $30 \mathrm{~cm}$ apart with row length of $5 \mathrm{~m}$. Thinning of seedlings was done after 15 days after sowing and plant to plant distance was maintained at 15 centimeters. A basal dose of $50 \mathrm{~kg} \mathrm{ha}^{-1}$ each of
$\mathrm{P}_{2} \mathrm{O}_{5}$ and $\mathrm{K}_{2} \mathrm{O}$ along with nitrogen $100 \mathrm{~kg} \mathrm{ha}^{-1}$ was applied through single super phosphate, muriate of potash and urea respectively. All recommended package and practices were followed to raise good crop.

Five plants were randomly selected and the observations were recorded in respect of various characters in each genotype. The average values of observations on these five plants were used as treatment mean in all statistical analysis. The observations included days to first flowering, days to $50 \%$ flowering, plant height at 90 DAS $(\mathrm{cm})$, stem diameter (cm), number branches per plant, number of inflorescence per plant, inflorescence length (cm), number of panicles per inflorescence, panicle length $(\mathrm{cm})$, panicle breadth $(\mathrm{cm})$, days to seed maturity, thousand seed weight $(\mathrm{mg})$, seed protein content $(\%)$, seed yield per plant $(\mathrm{g})$. The protein content of seeds from each variety was estimated as per the Lowry's method and expressed in per cent (Lowry et al., 1951). Estimates of phenotypic and genotypic co-efficients of variation, heritability, and genetic advance were computed according Burton and Devane (1953) and Johnson et al. (1955) respectively.

\section{Results and Discussion}

The statistical analysis showed highly significant differences among the genotypes for all the characters studied, indicating considerable amount of genetic variation in the material (Table 1). The mean, range, variance, co-efficient of variation, heritability and genetic advance for fourteen traits including grain yield are presented in the Table 2. The highest value of phenotypic coefficient of variation (PCV) and genotypic coefficient of variation (GCV) were observed for number branches per plant (90.64 and 93.96 $\%$ ), followed by number of panicles per inflorescence (83.29 and $87.85 \%$ ), number of inflorescence per plant (68.84 and $74.83 \%)$, 
panicle length $(\mathrm{cm})(64.28$ and $68.29 \%)$, panicle breadth $(\mathrm{cm})$ (40.68 and $43.50 \%)$, thousand seed weight (mg) (34.66 and $34.66 \%)$, seed yield per plant (g) (29.77 and $35.50 \%)$, stem diameter $(\mathrm{cm})(29.85$ and $31.57 \%)$, plant height at 90 DAS (cm) $(28.37$ and $29.64 \%)$, inflorescence length $(\mathrm{cm})(27.73$ and $32.09 \%)$, seed protein content (22.11 and $22.13 \%)$ and days to first flowering (21.30 and $21.83 \%$ ). Higher values of PCV with corresponding higher values of GCV in these traits suggest that these characters are under the influence of genetic control. Hence, these characters can be relied up on and simple selection can be practiced for further improvement of these traits. Similar kind of results have been reported by Venkatesh et al., (2014) for stem girth, number of leaves per plant, plant height, panicle length and seed yield per plant. Patial et al. (2014), Yadav et al. (2014), Akaneme and Ani, (2013), Selvan et al. (2013) and Sravanthi et al. (2012) for the seed yield. Moderate PCV and GCV are estimated for days to fifty per cent flowering, whereas days to seed maturity showed lower values of phenotypic and genotypic coefficient of variation, which is in conformity with the findings of Venkatesh et al. (2014), Patial et al. (2014) and Rana et al. (2005). Thus, for improvement of these traits there is need for creating variability through introduction and hybridizing the diversified genotypes to generate transgressive segregant.

Phenotypic coefficient of variation (PCV) was higher than the genotypic coefficient of variation $(\mathrm{GCV})$ for all the traits indicating that environmental factors were influencing their expression. Wide difference between phenotypic and genotypic coefficient of variations was observed for number of inflorescence per plant, inflorescence length $(\mathrm{cm})$, number of panicles per inflorescence and seed yield per plant (g) indicated their sensitiveness to environmental fluctuations whereas rest of all traits showed narrow difference indicating less environmental interference on the expression of these traits.

Effectiveness of selection depends not only on the nature of gene combination of individual genes; but also influenced strongly by the degree to which phenotype can be modified by environment, selection acts on genetic differences and benefit from selection for a particular trait depends largely on its heritability (Allard, 1960). Thus it is evident that the co-efficient of variation alone may not reveal the actual situation of heritable nature of the trait. Hence, to obtain more information on heritable portion of the variability, it is essential to know the heritability estimates of different characters. In view of Burton (1952) GCV along with heritability would provide a precise idea to the amount of genetic gain to be expected from selection. High estimates of broad sense heritability were observed for all the characters studied, but high heritability does not always indicate high genetic gain, heritability with genetic advance should be used in predicting selection of superior genotypes (Ali et al., 2002). High estimate of heritability coupled with high genetic advances over mean were observed for the characters viz., plant height at 90 DAS, stem diameter, number of branches per plant, number of inflorescence per plant, number of panicles per inflorescence, panicle length, panicle breadth, thousand seed weight and seed yield per plant. Similar observation were made by Venkatesh et al. (2014) for stem girth, panicle length, panicle width and seed yield per plant in Amaranthus spp., similar observation also made by Sravanthi et al. (2012), Selvan et al. (2013), Yadav et al. (2014), Mobina and Jagatpati (2015) in amaranth for traits like plant height, stem diameter, number of branches per plant and seed yield. This indicated predominance of additive genetic component in expression of these traits. 
Table.1 Analysis of variance (mean squares) for different growth and quality parameters for seed yield parameters in amaranth genotypes during rabi season

\begin{tabular}{|c|c|c|c|c|c|c|}
\hline \multirow[t]{2}{*}{$\begin{array}{c}\text { Sl } \\
\text { No }\end{array}$} & Source of variation/characters & Replication & $\begin{array}{c}\text { Treatment } \\
\text { (Genotypes) }\end{array}$ & Error & C.D. $(1 \%)$ & C.D. $(5 \%)$ \\
\hline & Degree of freedom & 1 & 43 & 43 & & \\
\hline 1. & Days to first flowering & 0.01 & 123.82 & 3.05 & 4.71 & 3.52 \\
\hline 2. & Days to $50 \%$ flowering & 1.37 & 125.85 & 2.44 & 4.21 & 3.15 \\
\hline 3. & Plant height at 90 DAS $(\mathrm{cm})$ & 81.62 & 1018.95 & 44.57 & 17.99 & 13.46 \\
\hline 4. & Stem diameter $(\mathrm{cm})$ & 0.02 & 0.19 & 0.010 & 0.27 & 0.20 \\
\hline 5. & Number branches per plant & 0.045 & 19.11 & 0.68 & 2.23 & 1.66 \\
\hline 6. & Number of inflorescence per plant & 0.12 & 19.61 & 1.63 & 3.44 & 2.57 \\
\hline 7. & Inflorescence length $(\mathrm{cm})$ & 123.47 & 173.73 & 25.19 & 13.52 & 10.12 \\
\hline 8. & Number of panicles per inflorescence & 1.50 & 438.54 & 23.30 & 13.01 & 9.73 \\
\hline 9. & Panicle length $(\mathrm{cm})$ & 19.56 & 159.07 & 9.61 & 8.35 & 6.25 \\
\hline 10. & Panicle breadth $(\mathrm{cm})$ & 0.08 & 0.35 & 0.02 & 0.41 & 0.31 \\
\hline 11. & Days to seed maturity & 0.001 & 111.47 & 0.20 & 1.23 & 0.92 \\
\hline 12. & Thousand seed weight (mg) & 12.37 & 87680.97 & 11.00 & 8.93 & 6.68 \\
\hline 13. & Seed protein content $(\%)$ & 0.001 & 10.18 & 0.007 & 0.23 & 0.17 \\
\hline 14. & Seed yield per plant (g) & 1.44 & 30.93 & 5.38 & 6.25 & 4.68 \\
\hline
\end{tabular}

All significant at $1 \%$ level 
Table.2 Estimates of mean, range, components of variance, heritability and genetic advance for seed yield parameters in amaranth genotypes during rabi season

\begin{tabular}{|c|c|c|c|c|c|c|c|c|c|c|c|}
\hline $\begin{array}{l}\text { Sl. } \\
\text { No. }\end{array}$ & & Character & Mean \pm S.Em & Range & GV & PV & $\begin{array}{c}\text { GCV } \\
(\%)\end{array}$ & $\begin{array}{l}\text { PCV } \\
(\%)\end{array}$ & $\mathbf{h}^{2}$ & GA & $\begin{array}{c}\text { GAM } \\
(\%)\end{array}$ \\
\hline 1 & \multicolumn{2}{|c|}{ Days to first flowering } & $36.49 \pm 1.24$ & $23.00-48.00$ & 60.38 & 63.44 & 21.30 & 21.83 & 95.18 & 15.62 & 42.80 \\
\hline 2 & \multicolumn{2}{|c|}{ Days to $50 \%$ flowering } & $40.08 \pm 1.11$ & $25.50-52.50$ & 61.71 & 64.15 & 19.60 & 19.98 & 96.18 & 15.87 & 39.60 \\
\hline 3 & \multicolumn{2}{|c|}{ Plant height at 90 DAS $(\mathrm{cm})$} & $77.79 \pm 4.72$ & $44.17-133.00$ & 487.21 & 531.78 & 28.37 & 29.64 & 91.61 & 43.52 & 55.94 \\
\hline 4 & \multicolumn{2}{|c|}{ Stem diameter $(\mathrm{cm})$} & $1.00 \pm 0.07$ & $0.5-1.80$ & 0.09 & 0.10 & 29.85 & 31.57 & 89.39 & 0.58 & 58.19 \\
\hline 5 & \multicolumn{2}{|c|}{ Number branches per plant } & $3.35 \pm 0.59$ & $0-11.34$ & 9.21 & 9.90 & 90.64 & 93.96 & 93.06 & 6.03 & 180.17 \\
\hline 6 & \multicolumn{2}{|c|}{ Number of inflorescence per plant } & $4.36 \pm 0.90$ & $1.00-11.17$ & 8.99 & 10.63 & 68.84 & 74.83 & 84.63 & 5.68 & 130.47 \\
\hline 7 & \multicolumn{2}{|c|}{ Inflorescence length (cm) } & $31.08 \pm 3.55$ & $14.33-52.17$ & 74.27 & 99.46 & 27.73 & 32.09 & 74.67 & 15.34 & 49.36 \\
\hline 8 & \multicolumn{2}{|c|}{ Number of panicles per inflorescence } & $17.30 \pm 3.41$ & $1-52.18$ & 207.62 & 230.93 & 83.29 & 87.85 & 89.90 & 28.15 & 162.69 \\
\hline 9 & \multicolumn{2}{|c|}{ Panicle length $(\mathrm{cm})$} & $13.45 \pm 2.19$ & $1.16-38.50$ & 74.74 & 84.35 & 64.28 & 68.29 & 88.60 & 16.76 & 124.64 \\
\hline 10 & \multicolumn{2}{|c|}{ Panicle breadth $(\mathrm{cm})$} & $1.01 \pm 0.11$ & $0.52-3.18$ & 0.17 & 0.19 & 40.68 & 43.50 & 87.48 & 0.79 & 78.42 \\
\hline 11 & \multicolumn{2}{|c|}{ Days to seed maturity } & $92.14 \pm 0.32$ & $78.00-103.50$ & 55.63 & 55.84 & 8.10 & 8.11 & 99.62 & 15.34 & 16.65 \\
\hline 12 & \multicolumn{2}{|c|}{ Thousand seed weight (mg) } & $604.13 \pm 2.35$ & $\begin{array}{l}227.00- \\
1325.50\end{array}$ & $\begin{array}{c}43834.9 \\
9\end{array}$ & $\begin{array}{c}43845.9 \\
9\end{array}$ & 34.66 & 34.66 & 99.97 & $\begin{array}{c}431.2 \\
4\end{array}$ & 71.38 \\
\hline 13 & \multicolumn{2}{|c|}{ Seed protein content $(\%)$} & $10.20 \pm 0.06$ & $6.36-14.71$ & 5.09 & 5.09 & 22.11 & 22.13 & 99.84 & 4.64 & 45.51 \\
\hline 14 & \multicolumn{2}{|c|}{ Seed yield per plant (g) } & $12.01 \pm 1.64$ & $6.70-23.56$ & 12.77 & 18.16 & 29.77 & 35.50 & 70.33 & 6.18 & 51.44 \\
\hline & $\begin{array}{l}\text { GV } \\
\text { GCV } \\
\text { GA } \\
\text { GAM }\end{array}$ & $\begin{array}{ll}- & \text { Genotypic variance } \\
- & \text { Genotypic coefficient of vari } \\
- & \text { Genetic advance } \\
- & \text { Genetic advance over mean }\end{array}$ & $\begin{array}{ll} & \mathrm{PV} \\
\mathrm{PCV} & - \\
\mathrm{h}^{2} & -\end{array}$ & $\begin{array}{l}-\quad \text { Pheno } \\
\text { Phenotypic coe } \\
\text { Heritability }\end{array}$ & 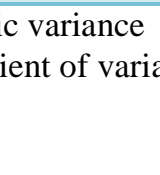 & & & & & & \\
\hline
\end{tabular}


Thus, there is scope for improvement of seed yield by adopting selection. Based on these traits, some of the promising genotypes in the genetic stock studied are G-4, G-20, G-27, G-32 and G-33 which have high seed yield per plant.

\section{References}

Akaneme, F.I. and Ani, G.O. 2013. Morphological assessment of genetic variability among accessions of Amaranthus hybridus. World Appl. Sci. J., 28

568-577.

Ali, A., Khan, S. and Asad, M. A. 2002. Drought tolerance in wheat: Genetic variation and heritability for growth ion relations. Asian J. Plant Sci., 1: 420-422.

Allard, R.W. 1960. Biometrical approach in plant breeding, Genetics in plant breeding. Brookhaven Sym., 9: 69-88.

Burton, G. W. and Devane, R. W. 1953. Estimating heritability in tall foscue (Festuca arubdinaces) from replicated clonal material. Agron. J., 45:478-481.

Burton, G.W. 1952. Qualitative inheritance in grasses. Proc. Internat. Grassland Congress, 1: 273-283.

Grubben G.J.H. 1976. The cultivation of amaranth as a tropical leaf vegetable. Trop. Inst. Amsterdam Communic., 67: 207.

Johnson, H. W., Robinson, H. F. and Comstock, R. S. 1955. Estimation of genetic and environmental variability in soyabean. Agron. J., 41: 314-318.

Lowry, O.H., Rosebrough, N.J., Farr, A.L., and Randall, R.J. 1951. Protein measurement with the Folin phenol reagent. $J$. Biol.Chem., 193- 265.

Mobina P. and Jagatpati, T. 2015. Genetic variability of Amaranthus hybridus in tropical plains of west Bengal. Int. J. Pure
App. Biosci., 3(2):389-395.

O'Brien, G., Kelly and Martin L.P. 1983. Amaranth: grain and vegetable. Echo Technical Notes, 1999.

Patial, M., Chauhan, A., Singh, K.P. and Sharma, D. 2014. Character association and path coefficient analysis in grain amaranth (Amaranthus spp.). Int. J. Agri. Envi. Biot., 6 (1): 101-106.

Rana, J. C., Yadav, S. K., Mandal, S. and Yadav, S. 2005. Genetic divergence and interrelationship analysis in grainnamaranth (Amaranthus hypochondriacus) germplasm. Indian $J$. Genet., 65(2): 99-102.

Selvan, R.K., Yassin, M.G. and Govindarasu, R. 2013. Studies on genetic parameters in grain Amaranthus (Amaranthus hypochondriacus 1.) as influenced by plant densities. J. Plant Breed. Genet., 01: 34-42.

Sravanthi, V., Begum, H., Sunil, N. and Medagam, T. R. 2012. Variance component analysis for grain yield and agro-economic traits in grain amaranths (Amaranthus spp.). Adv. Agri., Sci. Engi. Res., 2 (7): 233 - 244.

Sreelathakumary, I. and Peter, K.V. 1993. Amaranth - Amaranthus spp. In: Genetic Improvement of Vegetable Crops. Pergamon Press., 315-323.

Venkatesh, L., Murthy, N., Nehru, S.D. and Manjappa 2014. Genetic variability, heritability and genetic advance in grain amaranth (Amaranthus spp.). Asian $J$. Bio. Sci., 9 (1): 67-70.

Yadav, R., Rana, J.C. and Ranjan, J.K. 2014. Analysis of variability parameters for morphological and agronomic traits in grain amaranth (Amaranthus spp) genotypes. The bioscan, 9(4): 1661-1665.

\section{How to cite this article:}

Sheela N. Malaghan, S. Revanappa, P.S. Ajjappalavar, M.S. Nagaraja and Raghavendra, S. 2018. Genetic Variability, Heritability and Genetic Advance in Grain Amaranth (Amaranthus spp.). Int.J.Curr.Microbiol.App.Sci. 7(07): 1485-1494. doi: https://doi.org/10.20546/ijcmas.2018.707.175 